Journal of Language Teaching and Learning, Linguistics and Literature

\title{
The Effectivenness Of Simon Says Game In Teaching Vocabulary To The Second Year Students Of Smp Negeri 1 Palopo
}

\author{
Felogau \\ felogau@yahoo.com \\ Universitas Satya Wiyata Mandala, Nabire Papua
}

Received : 8 Mei 2018; Accepted : 21 Mei 2018

URL : http://ejournal.iainpalopo.ac.id/index.php/ideas

\begin{abstract}
The objectives of this research were: (1) To find out whether the use of simon says game effective or not to improve the students' vocabulary at the second year of SMP Negeri 1 Palopo and (2) What are the students' responses in learning vocabulary by using simon says game. This research employed pre experimental design. The population of this research was the second year students of SMP Negeri 1 Palopo, which consisting of eight classes in 2016/2017 academic year. The total number of population was 290 students. This research used purposive sampling technique. The sample of this research was one class as an pre experimental class. The sample of the class was 20 students. The research data was collected by using vocabulary test to get the students' vocabulary achievement, which was analyzed by inferential statistic through SPSS version 20.0 for windows program. The students' result of posttest of pre experimental class is significantly improved than the students' result of pretest by the mean score $68.00>50.10$. The difference of both scores is statistically significant based on the t-test value at significant level 0.05 in which the probability value is lower than the significant level $(0.00<0.05)$. So, $H_{1}$ was accepted and $\mathrm{H}_{0}$ was rejected. It can be concluded that the use of Simon says game effective to improve the students' vocabulary and the students also gave positive responses in learning vocabulary by using Simon says game.
\end{abstract}

Keywords: Simon says game; vocabulary 
The Effectiveness of Simon Says Game in Teaching Vocabulary to the Second Year Students of SMP Negeri 1 PALOPO

\section{Introduction}

English as a foreign language involves four language skills. They are listening, speaking, reading and writing, the four language skills are developed from four language components: structure, vocabulary, spelling, and pronunciation. In this research the researcher's attention focuses on vocabulary as one of the English language components.

Vocabulary is the most important thing in learning English. It should be given a priority and attention than other skills, because knowledge of vocabulary is a key to understand the skills in English. Student cannot convey their ideas in written and spoken form without having a sufficient number of vocabularies. So, it is not wrong if we say, there are only two things that we need to be learned when we study a foreign language, namely word and how to put them together to be a good sentence.

There are many games that teacher has applied to increase students' vocabulary, but in fact the number of the students' vocabulary is still very low, and based on my preliminary observation, particularly for students at SMP Negeri 1 Palopo, many students there still lack of vocabulary, if the teacher asked them to do an exercise, they were difficult to do it. Vocabulary is not a simple matter, because learning thousand of words by heart make the students bored if the direction of acquiring and having sufficient vocabulary cannot make them interested.

That is why, many interesting games can be applied to serve the vocabulary of students. One of them that the researcher offers is simon says game, simon says game can be used to teach vocabulary, it is the game in which one person gives commands, the others have to carry them out, the trick is that they must only obey commands that are preceded by "simon says". The rules of this game are:

a. The students must follow the command if the command is preceded by the words "simon says".

b. The students must not follow the command if it is not preceded by the words "simon says".

c. If the students follow the command which is not preceded by "simon says", they should "out" from the game.

Simon says game is a game who involves students to follow the command and the steps in this game acquaints students for learning vocabulary with fun. Based on the explanation above, the researcher was interested in focusing a research, with the title "The Effectivenness of Simon Says Game in Teaching Vocabulary to the Second Year Students of SMP Negeri 1 Palopo"

Long and Richard (1987:305), vocabulary is an essential component of 
all uses language. Then, it would be impossible to learn a language without it. That is why the mastery of vocabulary can smoothen the way to success in mastering the language skills.

Richard and Renandya (2002:255), vocabulary is a core component of language proficiency and provides much of the basis for how well learners listen, speak, read and write.

Then, Webster (1990: 1370) defines vocabulary:

1. A list or collection of words and phrase usually alphabetically arrange and explain to defined lexicon.

2. A sum or stock of words employed by a language group, individually or word in field of knowledge.

In addition, Hornby (1974: 78) defines vocabulary as:

1. Total number of words (either rules for combination them) make up the language.

2. Range of words known to or used by person in a trade, profession, etc.

3. Book containing a list of words used in a book etc. usually with definition or translation.

Furthermore, in Oxford Learner's Pocket Dictionary, New Edition (1995) vocabulary is the total number of word in a language, words known to a person; last of words with their meanings, especially at the back of for teaching a foreign language.

In respect to the definition of vocabulary, the researcher concludes that vocabulary is one of the language components that have an important role in mastering English, it would be impossible for someone to speak a language without it.

\section{Simon Says Game}

Dictionary.reference.com concludes definition of simon says game as follow :

1. simon says game is a children's game in which all players must imitate only those movements and commands of a leader that are preceded by the words "Simon says.".

2. And it is a children's game in which players must obey the leader's instructions if they are prefaced with "Simon says"

Then www.definitions.net/definition/Simon states that simon says is a child's game for 3 or more players where 1 player takes the role of "Simon" and issues instructions to the other players, which should only be followed if prefaced with the phrase "Simon says", for example, "Simon says, jump in the air". Players are eliminated from the game by either following instructions that are not immediately preceded by the trigger phrase or by failing to follow an instruction which does include the phrase "Simon says". It is the ability to distinguish between valid and invalid commands, rather than physical ability, that usually 
The Effectiveness of Simon Says Game in Teaching Vocabulary to the Second Year Students of SMP Negeri 1 PALOPO

matters in the game; in most cases, the action just needs to be attempted. The object for the player acting as Simon is to get all the other players out as quickly as possible; the winner of the game is usually the last player who has successfully followed all of the given commands. Occasionally however, 2 or more of the last players may all be eliminated by following a command without "Simon Says", thus resulting in Simon winning the game.

According to Supardi (2011) states that simon says game is the game in which one person gives commands, the others have to carry them out, the trick is that they must only obey commands that are preceded by "simon says". To focus attention on its use for vocabulary teaching, one technique migbt be to teach the parts of the face or action verb : touch your eyebrows, touch your cheeks, simon says touch your nose. The teacher introduces the vocabulary needed, and the students carry out the actions in due course the students may take over the ordering role. They are reacting to the new vocabulary with physical movements, they are doing something that will help them to remember. By using simon says game the students can be required to make active, meaningful use of new vocabulary immediately.

Here are the rules of simon says game:

1. The students must follow the command if the command is preceded by the words "simon says".

2. The students must not follow the command if it is not preceded by the words "simon says".

3. If the students follow the command which is not preceded by "simon says", they should "out" from the game.

\section{Method}

This research applied a pre-experimental research method. It involved a group of students. Pre-experimental was design using pre-test and post-test. Pre-test was held before treatment and post-test after treatment. In conducting the research there were variables, independent and dependent variable, where the independent variable was simon says game as teaching technique and dependent variable was the students' improvement on vocabulary. The population of this research was the second year students of SMP Negeri 1 Palopo in academic year 2016/2017, which consisted of eight classes. The total number of population was 290 students. The researcher used purposive sampling technique and took one class as the sample of the research and the class was V111A class. So, the total number of sample was 20 students and the researcher took them as respondents. In order to collect the data, the researcher used vocabulary test and questionnaire. Vocabulary test was used to get the students' vocabulary improvement and questionnaire to know about 
the students' responses in learning vocabulary by using simon says game. To analyze the test result, the researcher used technique analysis. The use of percentage technique analysis was to know the percentage of students' vocabulary achievement through simon says game. To find out the mean score, standard deviation, and t-test by using SPSS 20.0 program.

\section{Results}

a. Rate percentage of students' score on pretest

Table 1. The rate percentage of pretest score of the pre-experimental group

\begin{tabular}{llccc}
\hline \multirow{2}{*}{ No } & \multirow{2}{*}{ Classification } & \multirow{2}{*}{ Score } & \multicolumn{2}{c}{ Pre experiment } \\
\cline { 3 - 5 } & & $\mathrm{F}$ & $\%$ \\
\hline 1. & Excellent & 96 to 100 & 0 & 0 \\
2. & Very Good & 86 to 95 & 0 & 0 \\
3. & Good & 76 to 85 & 0 & 0 \\
4. & Fairly Good & 66 to 75 & 1 & $5 \%$ \\
5. & Fair & 56 to 65 & 2 & $10 \%$ \\
6. & Poor & 36 to 55 & 17 & $85 \%$ \\
7. & Very poor & 00 to 35 & 0 & 0 \\
\hline & $\quad$ & 20 & $100 \%$ \\
\hline
\end{tabular}

b. Rate percentage of students' score on posttest

Table 2. The rate percentage of posttest score of the pre-experimental group

\begin{tabular}{llccc}
\hline \multirow{2}{*}{ No } & \multirow{2}{*}{ Classification } & \multirow{2}{*}{ Score } & \multicolumn{2}{c}{ Pre experiment } \\
\cline { 4 - 5 } & & & $\mathrm{F}$ & $\%$ \\
\hline 1. & Excellent & 96 to 100 & 0 & 0 \\
2. & Very Good & 86 to 95 & 0 & 0 \\
3. & Good & 76 to 85 & 6 & $30 \%$ \\
4. & Fairly Good & 66 to 75 & 4 & $20 \%$ \\
5. & Fair & 56 to 65 & 10 & $50 \%$ \\
6. & Poor & 36 to 55 & 0 & 0 \\
7. & Very poor & 00 to 35 & 0 & 0 \\
\hline & $\quad$ Total & & 20 & 100 \\
\hline
\end{tabular}

After calculating the result of the students' pretest, the mean score and standard deviation are presented in following table:

Table 3. The mean score and standard deviation of the students' pretest

\begin{tabular}{ccc}
\hline Group & Mean Score & Standard Deviation \\
\hline Pre experimental & 50.10 & 5.821 \\
\hline
\end{tabular}


The Effectiveness of Simon Says Game in Teaching Vocabulary to the Second Year Students of SMP Negeri 1 PALOPO

Having calculated the students' pretest, the next test to be analyzed is posttest. The following is the table that describes the mean score and standard deviation of the students' posttest.

Table 4. The mean score and standard deviation of the students' posttest

\begin{tabular}{ccc}
\hline Group & Mean Score & Standard Deviation \\
\hline Pre experimental & 68.00 & 5.947 \\
\hline
\end{tabular}

Response of the Students

In this part, the researcher distributed the same question to the students of SMP Negeri 1 Palopo about their response of using simon says game in teaching vocabulary specified for the second (VIIIA) year students.

The question is: Senangkah kalian belajar kosakata bahasa inggris dengan menggunakan simon says game?

These are the transcription of students' response about simon says game:

\begin{tabular}{|c|c|l|}
\hline No & Students' Code Name & Students' Response \\
\hline 1. & CLA & Senang \\
\hline 2. & EPI & Senang \\
\hline 3. & DSI & Senang \\
\hline 4. & AVR & Senang \\
\hline 5. & ASN & Sangat menyenangkan \\
\hline 6. & DNI & Senang sekali \\
\hline 7. & SRN & Sangat senang \\
\hline 8. & GGN & Senang \\
\hline 9. & ITN & Sangat senang \\
\hline 10. & NTL & Amat senang \\
\hline 11. & KME & Senang sekali \\
\hline 12. & DWN & Senang \\
\hline 13. & NLA & Senang \\
\hline 14. & NEL & Sangat senang \\
\hline 15. & AJN & Senang \\
\hline 16. & INL & Senang \\
\hline 17 & APS & Senang \\
\hline 18 & HBP & Senang \\
\hline 19. & EMI & Senang \\
\hline 20. & FDO & \\
\hline
\end{tabular}

The description of the data collects through vocabulary test as explained in the previous section shows that the students' ability improves significantly. It 
is supported by the result of the students' pre-test and post-test. The data in previous section shows that the use of simon says game is effective in improving students' vocabulary. It is supported by the mean score of post-test (68.00) which is categorized as fairly good and the mean score of pre-test (50.10) which is categorized as poor.

The data indicates that the use of simon says game effective to improve the students' vocabulary achievement.

Based on the result of T-Test, the researcher finds that the p-value of posttest is lower than $\alpha(0.00<0.05)$. The t-test value of post-test is remarked significant difference. It indicates that the alternative hypothesis $\left(\mathrm{H}_{1}\right)$ is accepted and of course, the null hypothesis $\left(\mathrm{H}_{0}\right)$ is rejected. It is proved that the use of simon says game in improving students' vocabulary is effective.

Supardi (2011) states that simon says game is the game in which one person gives commands, the others have to carry them out, the trick is that they must only obey commands that are preceded by "simon says". To focus attention on its use for vocabulary teaching, one technique migbt be to teach the parts of the face or action verb : touch your eyebrows, touch your cheeks, simon says touch your nose. The teacher introduces the vocabulary needed, and the students carry out the actions in due course the students may take over the ordering role. They are reacting to the new vocabulary with physical movements, they are doing something that will help them to remember. By using simon says game the students can be required to make active, meaningful use of new vocabulary immediately.

Another fact shows that the use of simon says game gives better effect to the students, it is proved by the students' response, all the students gave positive response. This is implies that the use of simon says game in learning vocabulary is a good technique because the students feel enjoyable and easier to understand the material.

\section{Conclusion}

The data shows that the use of simon says game in improving students' vocabulary is effective. The students' score in post-test is improved and it can be seen from the result of post-test to prove it. The use of simon says game improves students' achievement in vocabulary, it is shown by the students' result in posttest. Mean score of students' posttest is higher than pretest $(68.00$ $>50.10)$ so, it is significant difference. The probability value is smaller than $\alpha$ $(0.00<0.05)$, it indicates that the alternative hypothesis $\left(H_{1}\right)$ is accepted and the null hypothesis $\left(\mathrm{H}_{0}\right)$ is rejected. It means that students' vocabulary can improve by using simon says game at the second year students of SMP Negeri 1 Palopo and the students also gave positive responses in learning vocabulary by using simon says game.

Teacher should give the exact technique in teaching vocabulary. The 
The Effectiveness of Simon Says Game in Teaching Vocabulary to the Second Year Students of SMP Negeri 1 PALOPO

students should be given materials by using "simon says game in improving their vocabulary". The teacher and the next researcher should be more creative in giving the best technique in teaching English, not only in vocabulary component but also another component in English. Due to its limitation, the present research is just held six times for treatments, so it is not maximized. Therefore, it is suggested that there should be a further research with more exercises on component to be improved.

\section{References}

Dictionary.reference.com/browse/simon+say. Accesed on 2016-03-21.

Hornby, A.S. (1974). Oxford Advanced Learner's Dictionary of Current English. Tokyo: London Oxford University Press.

Hornby, (1995). Oxford Advanced Learner's dictionary of Current English. London : Oxford university Press.

Long, Michael H and Richard Jack C. (1987). Methodology in TESOL : A Book of Reading. Boston, Massachusetts: Newbury House Publishers.

Richards and Willy A Renandya. (2002). Methodology in Language Teaching : An Anthology of Current Practice. Cambridge: Cambridge University Press.

Supardi. (2011). Teaching Vocabulary by Using Simon Says Games at the First Year Students of SMP Negeri 1 Baebunta. Unpublished Thesis of STAIN Palopo.

Webster, Mariam. (1990). Webster's ninth New Collegist Dictionary. Massachusetts: Meriam - webster Inc. Publisher. www.definitions.net/definition/Simon 